\title{
4 \\ The digital economy in Southeast Asia: Emerging policy priorities and opportunities for regional collaboration ${ }^{1}$
}

\author{
Natasha Beschorner
}

\section{Introduction}

Southeast Asia's digital economy ${ }^{2}$ is expanding at an unprecedented rate. This is evidenced by the rise of technology 'unicorn' companies valued at more than US\$1 billion (four of which are in Indonesia), cross-border e-commerce platforms and the growing number of entrepreneurs who are innovating and using technology to grow. The use of digital technologies has the potential to transform-indeed, disrupt-all sectors of the economy, from logistics and finance to agriculture and social services.

\footnotetext{
1 This chapter summarises the findings of a recent World Bank report, The Digital Economy in Southeast Asia: Building the foundations for future growth (Beschorner et al. 2019), focusing on key policy enablers. Also see World Bank (2019).

2 The term 'digital economy' is used to refer to private-sector utilisation of digital technologies as a driver of economic growth, innovation and other means of transforming the economy. In this sense, the digital economy is not restricted to the information and communication technology (ICT) sector, but rather encompasses the adoption of digital technology in all sectors of the economy.
} 
These developments have also spurred increased interest from the region's governments and regional organisations, in promoting faster and more inclusive digitisation and technology adoption in various sectors. However, the full potential of technology as a driver of private-sector and wider economic growth is not yet being realised. Southeast Asia still faces significant barriers to growing its digital economy, many of which need to be addressed through enabling policies and regulations, as well as greater regional cooperation and collaboration. This chapter focuses primarily on these policy and regulatory factors.

\section{Regional digital economy overview}

The emergence and growth of the digital economy in Southeast Asia are being driven by improved internet access and usage across the region (Figure 4.1). Individuals in the region's emerging markets are spending substantial time online-more than four hours per day, for example, in Thailand, Malaysia and the Philippines.

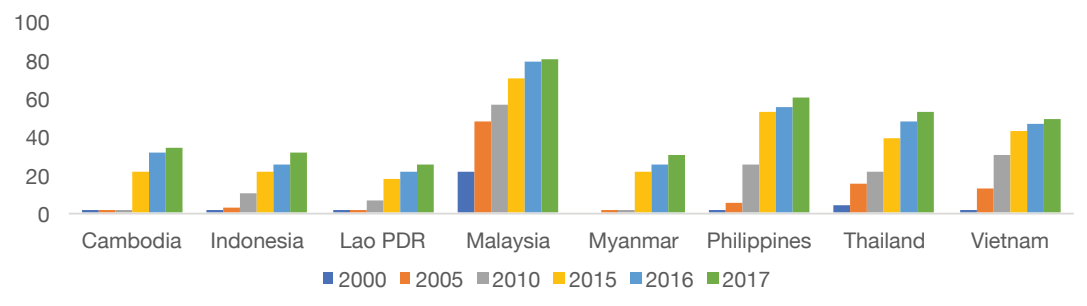

Figure 4.1 Individuals using the internet in selected Southeast Asian economies (percentage of population)

Source: World Bank staff calculations using World Bank (2021b).

According to recent surveys on internet usage, about 80 per cent of consumers regularly obtain information on products and services from social media (Kemp 2017). E-commerce spending in the region is also rising (Figure 4.2), facilitated by marketplaces/platforms where small and medium enterprises can also sell to consumers online. In big cities, the use of smartphones for messaging and social media has become ubiquitous. Ridesharing and delivery services using apps to obtain bookings are rapidly changing the face of urban transport and logistics services. 


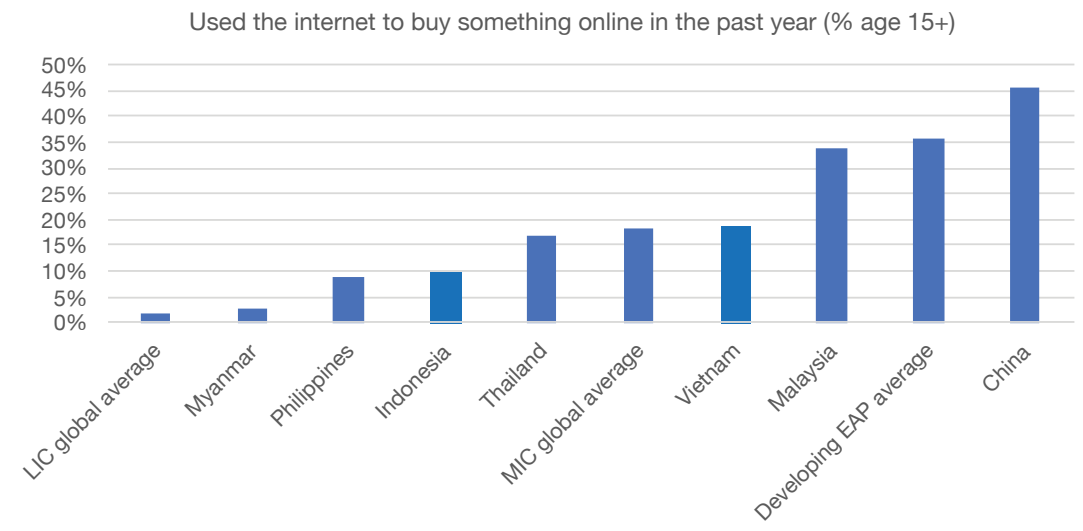

Figure 4.2 E-commerce adoption by country, 2017

$\mathrm{LIC}=$ low-income country

$\mathrm{MIC}=$ medium-income country

EAP $=$ East Asia and the Pacific

Source: World Bank (2018a).

Digital platforms - a combination of technical innovation, new business models and value proposition - in the private and, in some cases, the public sectors offer a range of products and services via digital channels. Platform-based businesses have experienced remarkable growth and further expansion is projected.

The internet has dramatically lowered the cost of delivering services, as well as marketing, ordering and paying for them. Total Association of Southeast Asian Nations (ASEAN) trade in telecommunications, computer and information services (adding exports and imports) almost doubled between 2010 and 2016 (Figure 4.3) and its share of total ASEAN services trade grew by 28 per cent.

Digital technologies are facilitating payment and lending, promoting financial inclusion. In 2016, investments in the Southeast Asian fintech market increased to US\$252 million-up one-third from 2015; the upward trend continued in 2017. The fintech landscape is dominated by payments and mobile wallets (43 per cent), followed by financial comparison platforms (15 per cent) and retail investment portals (11 per cent) (UOB 2017). Digital content development is another significant growth area. Ad-based video-on-demand (AVOD) or user-generated content platforms such as YouTube are very popular in Southeast Asia, with Vietnam and 
Thailand ranking among the 10 markets with the highest viewership globally (Fujita 2017). The growing volume of local content highlights the increasing adoption by local media companies of digital platforms for the delivery of news and entertainment.

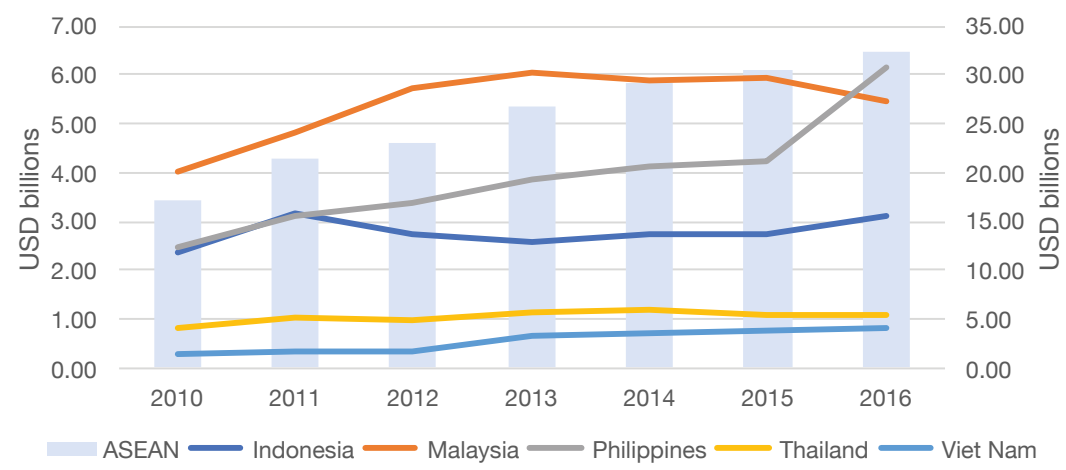

Figure 4.3 Telecommunications, computer and information services trade, ASEAN member countries

Note: Figure shows exports plus imports, for trade with all countries, to indicate the overall growth of trade rather than trade in one direction or another. The bars refer to the scale on the right axis, the lines to the scale on the left axis.

Source: Authors' calculations using information from ASEAN Secretariat.

However, the broader diffusion of digital technologies among businesses in Southeast Asia is still low, as illustrated by the World Bank's Digital Adoption Index (DAI) (Figure 4.4). The DAI measures the relative adoption of digital technologies by individuals, businesses and governments, based on a standard set of indicators across 180 countries relative to their income level. For example, Malaysia performs well in overall digital adoption in comparison with some Organisation for Economic Co-operation and Development (OECD) countries, but scores below expectations for its income level for digital adoption by businesses. These findings are also confirmed by the results of World Bank enterprise surveys. The limited use of digital technology by firms in Southeast Asia may reflect the digital divide between large and smaller firms, as globally small and medium-sized enterprises (SMEs) lag in technology adoption at all levels of economic development (OECD 2017). Other factors include the lack of necessary digital skills or limited availability of affordable broadband internet. 


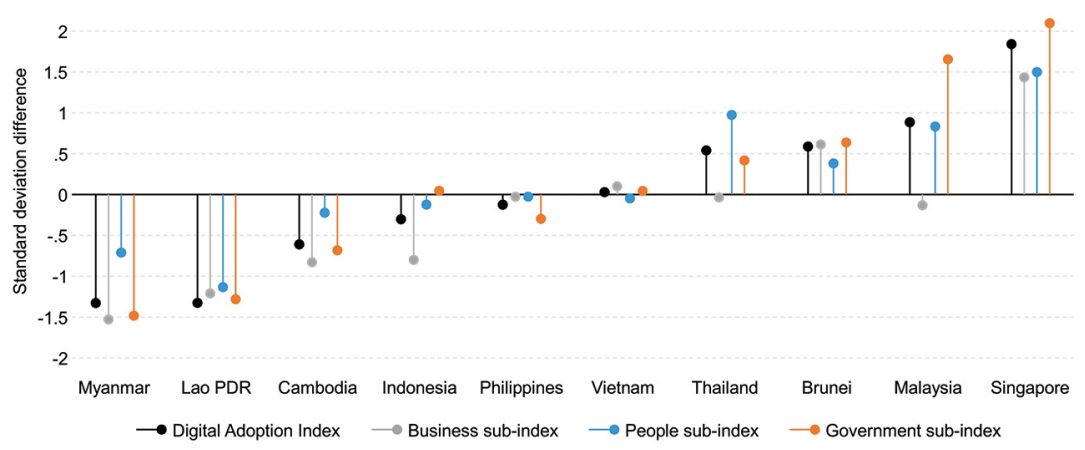

Figure 4.4 Digital adoption by individuals, governments and businesses relative to world average, ASEAN member countries ${ }^{3}$

Note: The diffusion of digital technologies among businesses uses proxy data such as the proportion of businesses with websites, the use of secure servers, internet bandwidth and mobile broadband.

Source: World Bank (2016b).

Looking ahead, digital technologies offer significant new opportunities for firms, including in lowering barriers to entry, particularly to global value chains (GVCs). SMEs may benefit disproportionately, as onceunaffordable computing power, storage and development platforms become cheaper (for example, via cloud computing), identifying talent becomes easier and markets become easier to reach (OECD 2017).

Emerging technologies such as fifth-generation (5G) mobile networksparticularly with their potential to expand the utilisation of device-todevice communications or the Internet of Things (IoT) - blockchainenabled distributed data management, big data analytics and machine learning/artificial intelligence have major potential for disrupting business models across economic sectors and service delivery mechanisms.

\section{Digital economy policy enablers ... or barriers?}

For the digital economy to have a significant impact on poverty reduction and inclusion in Southeast Asia, its key policy enablers or 'foundations' need to be better understood.

3 The overall DAI is the simple average of three subindexes, each of which comprises technologies necessary for the respective agent to promote development in the digital era: increasing productivity and accelerating broad-based growth for business, expanding opportunities and improving welfare for people and increasing the efficiency and accountability of service delivery for government (World Bank 2016a). 
These foundations, underpinned by a stable macroeconomic environment and supportive business environment, include affordable and consistent internet connectivity, secure payment systems and mechanisms, availability of appropriate and adaptable workforce skills, reliable logistics services to facilitate the delivery of goods and a series of crosscutting policies and regulations supporting and securing online transactions and protecting consumers (Table 4.1). This is essentially what the World Development Report 2016 (World Bank 2016b) refers to as the nondigital or 'analogue' complements needed to enable the digital economy and is discussed in more detail in The Digital Economy in Southeast Asia: Building the foundations for future growth (Beschorner et al. 2019).

\section{Table 4.1 Digital economy foundations at a glance}

\begin{tabular}{|l|l|}
\hline Connectivity & $\begin{array}{l}\text { Affordable, reliable and high-quality broadband internet } \\
\text { access is a prerequisite for and a physical underpinning of the } \\
\text { digital economy. }\end{array}$ \\
\hline Payments & $\begin{array}{l}\text { Access to safe and secure digital payment services provides } \\
\text { the opportunity to engage in electronic transactions whether } \\
\text { as consumers or entrepreneurs, domestically or overseas. }\end{array}$ \\
\hline Digital skills & $\begin{array}{l}\text { In a digitally driven economy, skills needs range from basic } \\
\text { digital and data literacy to specialised skills to harness the } \\
\text { productivity benefits of digital innovation. }\end{array}$ \\
\hline Logistics & $\begin{array}{l}\text { E-commerce is particularly dependent on well-regulated, } \\
\text { widely available and cost-effective logistics services given the } \\
\text { higher demand for delivery of goods, especially at low values, } \\
\text { both within and across borders. }\end{array}$ \\
\hline regulation & $\begin{array}{l}\text { Policies that promote trust are essential for growing } \\
\text { participation in the digital economy. These cover a range } \\
\text { of areas, from data privacy and cybersecurity to consumer } \\
\text { protection. Regional coordination of such policies is desirable. }\end{array}$ \\
\hline
\end{tabular}

There are significant differences between and within Southeast Asian countries in terms of internet access, speed and cost; in particular, differences within countries between urban and rural/remote internet access and quality can be especially large. The extent of utilisation of digital payments varies across countries. Significant gaps also exist between traditional models of education and training and the evolving demands for digital skills in the workforce. Policies and regulations for managing data, especially the flow of data across borders, are still evolving. 
4. THE DIGITAL ECONOMY IN SOUTHEAST ASIA

\begin{tabular}{|c|c|c|c|c|c|c|c|}
\hline 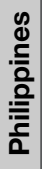 & $\begin{array}{l}\stackrel{\circ}{\circ} \\
\text { Oे }\end{array}$ & $\begin{array}{l}\text { مْ } \\
\stackrel{\circ}{\circ}\end{array}$ & ஓे & ळे & ڤે & ڤે̀ & $\mathscr{q}$ \\
\hline 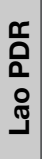 & $\frac{\circ}{i n}$ & $\stackrel{\text { Ф் }}{\check{c}}$ & $\stackrel{\circ}{\circ}$ & $\stackrel{\stackrel{\circ}{N}}{\sim}$ & 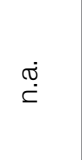 & $\stackrel{\text { ণ্் }}{\check{~}}$ & $\stackrel{\text { 욤 }}{\circ}$ \\
\hline $\begin{array}{l}\frac{\pi}{\sigma} \\
\frac{0}{0} \\
\frac{0}{\tilde{N}} \\
0\end{array}$ & $\begin{array}{l}\stackrel{\circ}{\hat{0}} \\
\hat{0}\end{array}$ & $\stackrel{\circ}{\stackrel{\circ}{\leftarrow}}$ & $\begin{array}{l}\stackrel{\circ}{\circ} \\
\stackrel{\circ}{r}\end{array}$ & $\begin{array}{l}\text { ஃे } \\
\text { षे }\end{array}$ & 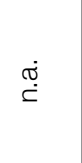 & $\stackrel{\text { ণ্் }}{\check{c}}$ & $\hat{n}$ \\
\hline $\begin{array}{l}\frac{\pi}{\sqrt{n}} \\
\frac{\sqrt{\pi}}{\sqrt{\pi}} \\
\frac{\pi}{2}\end{array}$ & $\begin{array}{l}\stackrel{\circ}{0} \\
\stackrel{0}{\leftarrow}\end{array}$ & $\begin{array}{l}\text { ठे } \\
\text { ○े }\end{array}$ & $\stackrel{\circ}{\infty}$ & $\begin{array}{l}\text { @े } \\
\text { co }\end{array}$ & ڤે & 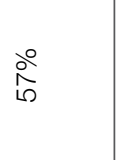 & $\widetilde{N}$ \\
\hline 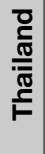 & $\begin{array}{l}\stackrel{\circ}{\circ} \\
\stackrel{2}{L}\end{array}$ & $\stackrel{\stackrel{一}{+}}{\stackrel{一}{~}}$ & $\begin{array}{l}\stackrel{0}{\mp} \\
\mp\end{array}$ & ঐें & 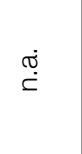 & 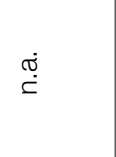 & $\hat{\imath}$ \\
\hline  & $\begin{array}{l}\stackrel{0}{\aleph} \\
\aleph_{0}\end{array}$ & $\stackrel{\stackrel{\circ}{+}}{\stackrel{-}{+}}$ & 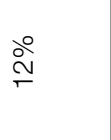 & $\stackrel{\circ}{\stackrel{N}{ }}$ & ○े & $\frac{\circ}{\frac{0}{10}}$ & $\stackrel{\infty}{\infty}$ \\
\hline 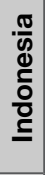 & $\begin{array}{l}\stackrel{\circ}{ } \\
\stackrel{8}{\circ}\end{array}$ & $\stackrel{\stackrel{\circ}{+}}{\stackrel{\circ}{+}}$ & $\begin{array}{l}\stackrel{\circ}{\check{m}} \\
\stackrel{0}{\circ}\end{array}$ & 号 & ஓ̊ & $\frac{\circ}{\frac{0}{6}}$ & 8 \\
\hline & 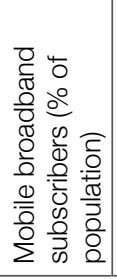 & 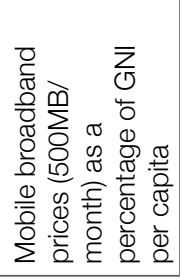 & 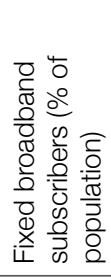 & 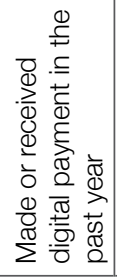 & 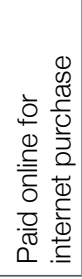 & 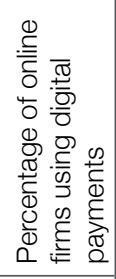 & 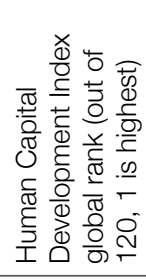 \\
\hline & 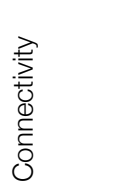 & & & 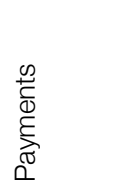 & & & $\frac{\frac{\omega}{\overline{\bar{r}}}}{\omega}$ \\
\hline
\end{tabular}


NEW DIMENSIONS OF CONNECTIVITY IN THE ASIA-PACIFIC

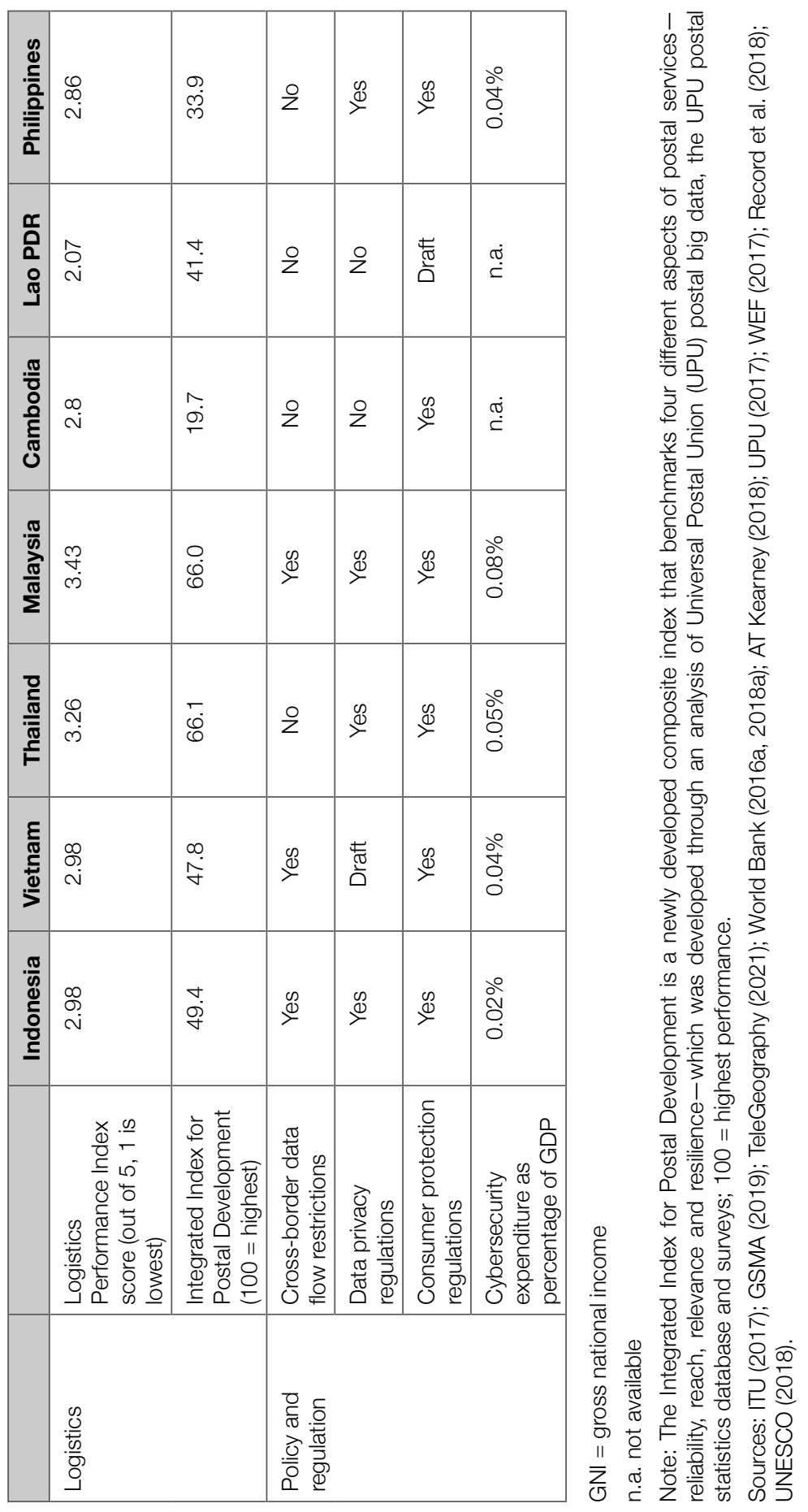




\section{Connectivity: Particularly high-speed (broadband) internet access}

Digital connectivity in Southeast Asia is improving, driven by substantial investment primarily from the private sector. Broadband internet penetration grew 13 per cent per year in Southeast Asia between 2011 and 2016 (ITU 2017). However, as of mid-2019, about half the region's population still lacked broadband access (Figure 4.5). Mobile broadband access (notably, 4G and, prospectively, 5G) is improving as is the proliferation of smartphones, but quality and affordability remain challenging in many areas. Fixed broadband access—-for example, through optical-fibre connections to the premises, which is essential for dataintensive transactions required by many businesses—is lagging.

Internet speeds - key determinants of service quality-in the largest Southeast Asian economies fall short of the global leaders, although the gap is closing. The largest middle-income developing countries in the region all fall below the OECD's average speed for mobile and fixed broadband. Thailand is the only economy ranked within the top-20 countries globally measured as the proportion of the population with broadband plans at 15 megabits per second (Mbps) or faster (Akamai 2017). Although Indonesia, the Philippines and Vietnam are currently behind, the year-on-year growth rates- 520 per cent, 509 per cent and 1,222 per cent, respectively, for 2016-17-are encouraging.

Internet affordability, both in absolute terms and as a percentage of income, has seen steady improvement globally and in Southeast Asia (ITU 2016, 2018). However, while mobile broadband is becoming more affordable-less than 5 per cent of gross national income (GNI) per capita ${ }^{4}$-fixed broadband is typically less affordable. There are also significant variations in the availability, quality and pricing of broadband services within countries, which are attributable to geography and population distribution (particularly in Indonesia and the Philippines), technical factors (such as the type of backhaul technologies available, such as fibre, microwave or satellite), overall costs of service deployment, expected revenue for service providers, local constraints such as permits and rights-of-way requirements and lower levels of competition in particular regions.

4 Gross national income (GNI) is defined as the sum of value added by all producers who are residents in a nation, plus any product taxes (minus subsidies) not included in output, plus income received from abroad such as employee compensation and property income. 


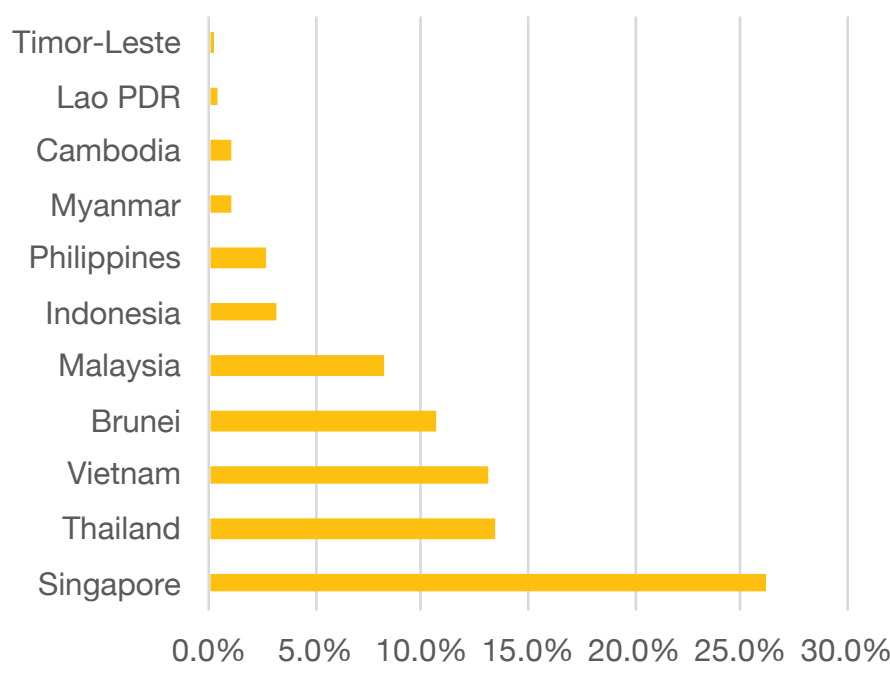

\section{Figure 4.5 Broadband internet penetration in ASEAN member countries (percentage of population)}

Notes: Mobile broadband means access to the internet using a $3 G$ or (faster) 4G-enabled device. A GSM 2G connection means that the user has only a basic data service-that is, text messaging. Fixed broadband means access to the internet using fixed-line networks such as XDSL (digital subscriber lines) or optical fibre connected to the premises. These data show the number of mobile and fixed broadband internet subscribers as a percentage of the population for each country.

Sources: ITU (2018); GSMA (2019); TeleGeography (2021).

Governments have an important role to play in facilitating faster broadband rollout through regulatory reforms that can, for example, improve competition in the broadband value chain (wholesale and retail) and help to optimise investments in unserved and underserved locations as well as increasing the uptake of services. Sound competition policy remains highly relevant in this regard, though the nature of the competitive landscape has shifted from voice-based to platform-based service delivery. Regulatory authorities also have an important role in quality-of-service oversight.

Priority policy and regulatory reforms for improved digital connectivity include the following.

- Open access and nondiscriminatory pricing: Regulations that help to create a more level playing field for telecommunications/internet service providers to access critical infrastructure/networks at all levels of the broadband value chain. This includes the 'first mile', 
or international gateway, as well as the 'middle mile' or 'backbone' networks and last-mile fixed networks-for example, fibre to the home (FTTH). Open access at the wholesale level helps to promote more equitable competition among retail service provides, lowering the cost of internet services at the retail level.

- Passive infrastructure sharing: Regulations that encourage or, in some cases, mandate service providers to share tower networks (for wireless backbone infrastructure, for example, microwaves and mobile base stations) and/or fixed broadband facilities to enable more efficient utilisation of resources and reductions in the cost of network installation and maintenance. Passive infrastructure may account for up to 80 per cent of digital infrastructure investment costs, so the savings are potentially significant. There are further opportunities for sharing digital infrastructure across sectors (for example, optical-fibre cables collocated with power transmission networks, roads and pipelines).

- Radio spectrum management: Spectrum is a scare resource, particularly in densely populated urban environments, which governments allocate-for example, to telecoms and broadcasting service providers, among others, to enable them to provide communications services across designated frequencies. Evolving communications technologies may require the review and/or reallocation of spectrum among service providers to maximise efficient utilisation. For example, the 700-megahertz band - typically allocated for analogue broadcastingis being progressively phased out globally as countries migrate to digital television. The spectrum can then be freed up for additional mobile broadband (for example, 4G) deployment.

- Foreign ownership restrictions that still apply in some countries in the telecommunications/internet sector: A review/revision of these may enable greater foreign investment in connectivity infrastructure and promote more competition in service delivery.

- National broadband plans: Several governments in the region have published such plans with indicative targets for coverage and internet speeds. Given the rapidly increasing demand, there is scope to set more ambitious targets for reducing the digital divide and to strengthen monitoring and evaluation mechanisms. 


\section{Payments}

Finance is both an enabler of the digital economy and one of the main sectors where digitisation is supporting significant changes in business models and available services. For example, digital financial services can potentially offer a new pathway into the formal financial system for 'unbanked' people in the region.

The use of digital payments in Southeast Asia is still lagging, constrained by low consumer awareness and lack of trust in the security and reliability of online transactions. Vietnam, Thailand, Indonesia and the Philippines fall below the middle-income country average (27 per cent) for account holders using the internet or mobile phones to access their accounts (Figure 4.6).

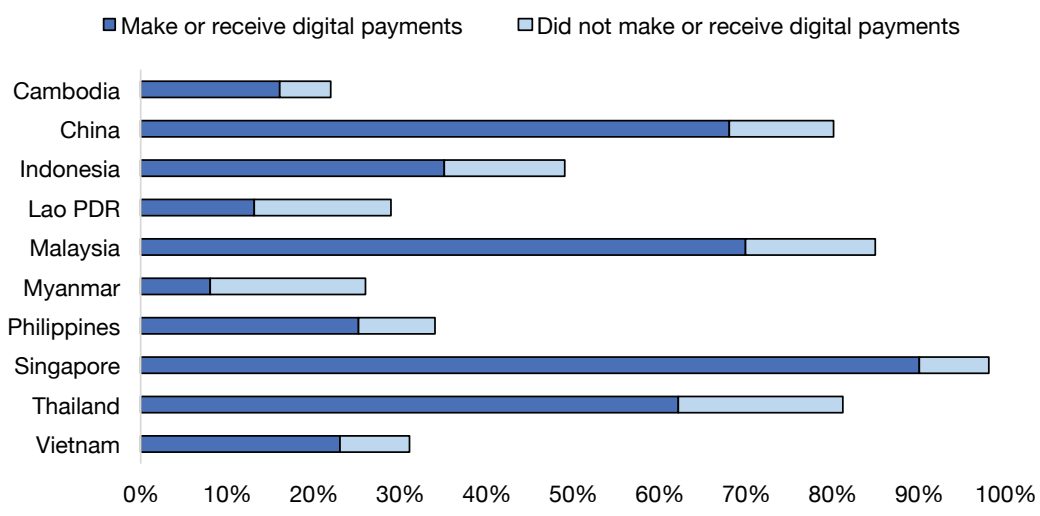

Figure 4.6 Digital payments use is still relatively limited

Source: World Bank (2018a).

The level of online payments for internet purchases in Thailand and Malaysia is roughly one-third lower than the average for middle-income countries (around 71 per cent), and around half the level in Singapore. In Vietnam, the use of online payments is 14 per cent that of the average for middle-income countries. About 85 per cent of account owners (70 per cent of adults) had made or received a digital payment in the year under review in Malaysia, but only around 35 per cent for Indonesia and 22 per cent for Vietnam (World Bank 2018a). 
Policymakers face a variety of challenges in facilitating the expansion of digital payments, including the following.

- Consumer protection, given that digital financial services and products are now being delivered through new channels and business models. These models challenge traditional thinking about disclosure and recourse-for example, if the consumer suffers a loss, liability can be unclear due to the multiple parties involved in service delivery such as intermediaries and third-party providers of communications and technology services. Policymakers will need to consider how to update conventional product standards and guidelines to address these concerns.

- Increased need for cross-sectoral coordination and communication. Digital financial inclusion-which involves new providers, services and consumers-requires significant cross-sectoral coordination and communication among regulators and supervisors, both at country and global levels. This is an important agenda item for regional organisations.

- Customer identity/digital identity document (ID). Financial identity for poor people when services are delivered digitally carries the potential for both inclusion and gains for anti-money laundering and countering the financing of terrorism, but it also raises privacy and fraud risks. Meaningful and manageable laws based on privacy principles-at the national and global levels - and effective enforcement thereof offer the prospect of win-win solutions. Policymakers, development partners and other stakeholders worldwide are also recognising the need to develop comprehensive ID programs to enable access to financial and other services.

- Monitoring systems. Reporting and monitoring systems need to become more sophisticated, with a greater focus on direct linkages to financial institutions' information systems (where feasible) and development of real-time monitoring capabilities, to enable implementation of appropriate privacy and data protections for users.

- Interoperability of digital services across service providers and points of service, including agents and service providers. This issue is critical for national efforts to broaden the reach of financial services into previously underserved, often rural, areas as well as for other fund transfers-for example, government services delivery. 


\section{Skills for the digital economy}

The growth of the digital economy is placing a premium on certain skills and reducing returns on others. Recent literature shows an emerging consensus around three 'tiers' of skills, outlined in Table 4.3, which are considered essential in the digital economy.

Structural changes in Southeast Asian economies have already been raising the demand for workers to have more advanced skills, but the digital economy is leading to more rapid changes in business models and activities. As a result, specific occupational skills are likely to become obsolete more quickly than in the past. Thus, skills policies should aim to build adaptability among workers, not just focus on specific occupations (World Bank 2016b: 259). The skill set for the digital economy is a combination of the 'soft' skills of critical thinking and problem-solving, communication, teamwork and creativity, beyond the traditional focus on 'hard' skills such as programming and coding, science and technology. This underlines the importance of governments investing in human capital, not only to build basic literacy and numeracy, but also to develop sociobehavioural skills, which also reinforce adaptability in a rapidly changing environment (World Bank 2019).

\section{Table 4.3 High-level digital skills categories}

\begin{tabular}{|l|l|l|l|}
\hline Types & Description & Target & Examples \\
\hline $\begin{array}{l}\text { Basic digital/ } \\
\text { ICT skills }\end{array}$ & $\begin{array}{l}\text { Ability to use digital } \\
\text { technologies (for example, } \\
\text { send emails, find work- } \\
\text { related information on } \\
\text { the internet, use digital } \\
\text { apps and nonspecialised } \\
\text { software, awareness of } \\
\text { and ability to stay safe in } \\
\text { cyberspace) }\end{array}$ & $\begin{array}{l}\text { All citizens and } \\
\text { workers }\end{array}$ & $\begin{array}{l}\text { EU: Digital } \\
\text { Competence } \\
\text { Framework for } \\
\text { Citizens, also known } \\
\text { as DigComp }\end{array}$ \\
\hline $\begin{array}{l}\text { Digital/ICT } \\
\text { complementary } \\
\text { skills }\end{array}$ & $\begin{array}{l}\text { Soft skills required to } \\
\text { work in a technology- } \\
\text { rich environment and to } \\
\text { participate in ICT-enabled } \\
\text { collaborative work (for } \\
\text { example, communicate via } \\
\text { social networks, market } \\
\text { products on e-commerce } \\
\text { platforms or analyse data } \\
\text { gathered from the web) }\end{array}$ & $\begin{array}{l}\text { Middle-skilled } \\
\text { to high-skilled } \\
\text { professionals }\end{array}$ & $\begin{array}{l}\text { US: Partnership for } \\
\text { 21st Century Skills } \\
\text { US: Agenda for } \\
\text { New Skills for Jobs }\end{array}$ \\
\hline
\end{tabular}

5 See, for example, OECD (2016); UNESCO (2018). 


\begin{tabular}{|l|l|l|l|}
\hline Types & Description & Target & Examples \\
\hline Advanced and & Skills needed to drive & Industry and & Global: Skills \\
specialist skills & innovation, support digital & occupation & Framework for the \\
& infrastructure and the & specific (for & Information Age \\
& functioning of the digital & example, program & (SFIA: www.sfia- \\
& ecosystem & software, develop & online.org/en) \\
& & applications, & Singapore: \\
& manage & Workforce \\
& networks, data & Qualification \\
& & analytics) & scheme \\
\hline
\end{tabular}

ICT = information and communication technology

Key policy priorities include the following.

- Digital skills strategy development and curriculum updates. These will need to be undertaken at all levels of education systems, as well as for lifelong learning programs. Some governments in Southeast Asia are already implementing programs to build a foundation of core skills to help workers meet the demands of increasingly technology-driven economic environments. Examples include Singapore's SkillsFuture for the Digital Workplace initiative, Malaysia's \#mydigitalmaker movement and Thailand's Net Pracharat skills awareness and digital literacy program. Given the rapid pace of changing skill needs, more systematic collaboration between governments and the private sector can help identify and anticipate these needs.

- Regional skills mobility. Regional efforts to promote talent mobility within ASEAN member countries, including providing for the transferability and recognition of education and skills through common certification protocols, will be important to reap the full benefits of technology and facilitate increased regional integration. Joint skills training and mutual recognition of occupational qualifications and standards between ASEAN nations also can promote talent flows from economies with specific skill surpluses to those where such skills are in short supply. This needs to be coupled with policies that support the regional movement of skilled personnel, which may require the lifting of restrictive policies in some country contexts.

\section{Logistics}

Improved connectivity, the spread of digital payments and adoption of e-commerce are all leading to higher demand for the delivery of goods within and across borders, raising the importance of logistics (trade facilitation and fulfilment) services. E-commerce consumers, whether 
firms or individuals, are demanding delivery services that are fast, efficient, reliable and traceable. Recent Logistics Performance Index (LPI) data ${ }^{6}$ indicate improved overall performance from 2016 to 2018 in Thailand, Vietnam, Indonesia, the Philippines and Lao PDR. In absolute terms, performance overall for ASEAN is not especially strong; only Thailand and Vietnam placed in the top 25 per cent of performers in the LPI in 2018, and Malaysia, Indonesia and the Philippines placed in the top 50 per cent. Figure 4.7 illustrates comparative performance on two key indicators from the LPI across selected countries: customs and border management, and the competence and quality of logistics services.

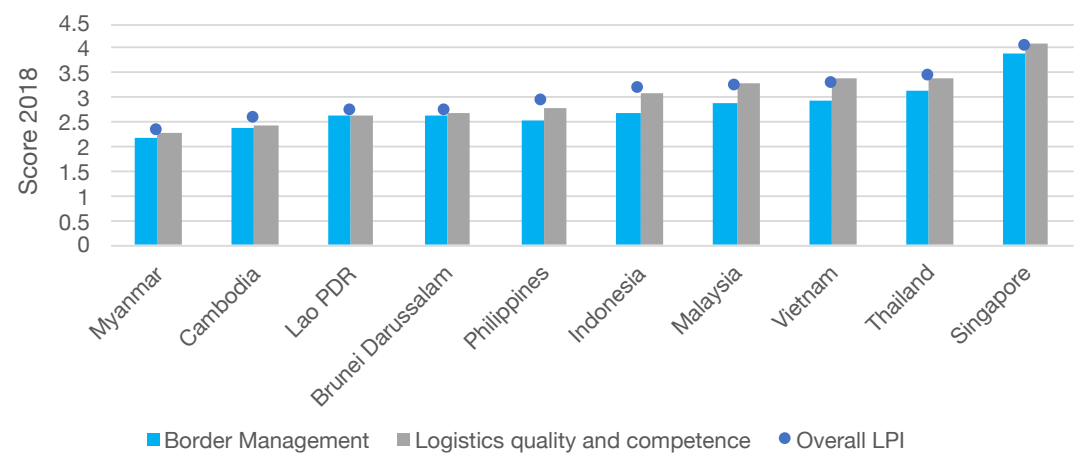

Figure 4.7 Logistics performance indicators: Selected key indicators, 2018

Source: World Bank (2018b).

Key policy and regulatory issues for governments related to logistics include the following.

- Harmonisation of 'de minimis' thresholds across countries. A particular feature of the growth of e-commerce is that it is leading to an increase in shipments of low-value, small consignments, both within and across borders. At present, most governments have de minimis thresholds in place, setting a value for individual shipments below which customs duties and other taxes are not charged. As the volume of goods falling below these thresholds grows, many governments perceive this as

6 The LPI collects the perceptions of logistics service providers about several aspects of logistics performance: 1) the efficiency of customs and border management clearances, 2) the quality of trade-related and transport-related infrastructure, 3) the ease of arranging competitively priced international shipments, 4) the competence and quality of logistics services, 5) the ability to track and trace consignments and 6) the frequency with which shipments reach consignees within the scheduled or expected delivery time. 
generating risk-for community protection and safety, revenue collection and intellectual property enforcement, among other areas. This has led to widely varying standards across countries. A common approach in Southeast Asia (for example, by ASEAN) is needed, and governments could facilitate cross-border e-commerce.

- Maintaining risk-based approaches to managing border clearances, including simplified procedures for low-value, low-risk goods and 'trusted trader' schemes for frequent traders with strong compliance records. Efficiency and control can be facilitated by ensuring that logistics operators or e-commerce firms provide data to customs agencies in advance of a parcel's arrival. The majority of small parcels crossing borders through e-commerce are likely to be legitimate shipments and inspecting all or most parcels will not only impede trade but also entail high administrative costs for customs and other agencies.

- Reducing internal regulatory barriers. These include phasing out fragmented licensing arrangements for logistics services and reducing market entry barriers-for example, foreign equity limits and minimum capital requirements that increase logistics costs in some countries, such as Indonesia.

- Facilitating provision of space, especially in urban areas, for warehouse and distribution facilities would enable more timely delivery of small parcels (e-commerce companies require up to three times the inventory space of 'offline' retailers) (Prologis 2016).

- Facilitating last-mile delivery in those Southeast Asian economies that still have large gaps in postal addressing, such as Indonesia and Myanmar, is critical, given the heavy reliance on postal networks for e-commerce deliveries. In Indonesia, for example, the lack of standardisation in addressing systems and parcel sizes requires the use of manual rather than automatic sorting, which is likely to push costs up as e-commerce demand grows. Alternative solutions (for example, pick-ups at supermarkets or parcel lockers) will be needed and in some cases have already been developed by private-sector firms and consumers. 


\section{Crosscutting digital economy policy and regulation}

Policies to promote trust in the internet and digital activities are essential for growing participation in the digital economy and for managing risks associated with technologies such as cloud computing, big data analytics, the IoT and, prospectively, artificial intelligence (AI) and machine learning. This includes policies and regulations on electronic transactions more broadly, but also specific measures addressing data protection and privacy-particularly the issue of cross-border data flows - cybersecurity and consumer protection. Other relevant crosscutting policies relate to digital entrepreneurship, digital government and digital identity programs.

Southeast Asian governments have generally adopted policies and regulations pertaining to e-commerce. This focus is also evident in ASEAN's regional digital agenda, which has a strong focus on e-commerce rather than the digitisation of industries. ASEAN member countries have adopted two UN Commission on International Trade Law (UNCITRAL) instruments, the Model Law on Electronic Commerce (MLEC) and, more recently, the Convention on Electronic Contracting. Both instruments prohibit discrimination against contracts originating in electronic form and disparity of treatment between electronic communications and paper documents. ${ }^{7}$ These prohibitions are regarded as 'enabling' e-commerce by removing doubts about the enforceability of online contracts. While multiple ASEAN jurisdictions have enacted domestic legislation based on either the MLEC or the convention, the adoption of the MLEC has not been uniform.

Most Southeast Asian countries-except Cambodia, Lao PDR and Myanmar-have general legal frameworks for secure electronic transactions, data protection and privacy and consumer protection for online purchases (see Table 4.4). Challenges include implementation and enforcement and development of subsidiary legislation and regulations to address the detailed issues outlined above.

7 See UNCITRAL (1999: Article 8, Explanatory Note, para. 129). 
Table 4.4 Legal frameworks in ASEAN countries for electronic transactions, data protection, privacy and online purchases

\begin{tabular}{|l|c|c|c|c|}
\hline Country & $\begin{array}{c}\text { Does the } \\
\text { country } \\
\text { have a legal } \\
\text { framework } \\
\text { for electronic } \\
\text { transactions/ } \\
\text { e-signatures? }\end{array}$ & $\begin{array}{c}\text { Does the } \\
\text { country } \\
\text { have a legal } \\
\text { framework } \\
\text { for data } \\
\text { protection/ } \\
\text { privacy online? }\end{array}$ & $\begin{array}{c}\text { Does the } \\
\text { country have a } \\
\text { legal framework } \\
\text { for consumer } \\
\text { protection when } \\
\text { purchasing } \\
\text { online? }\end{array}$ & $\begin{array}{c}\text { Does the } \\
\text { country } \\
\text { have a legal } \\
\text { framework } \\
\text { for } \\
\text { cybercrime } \\
\text { prevention? }\end{array}$ \\
\hline $\begin{array}{l}\text { Brunei } \\
\text { Darussalam }\end{array}$ & Yes & No & Yes & Yes \\
\hline Cambodia & Draft & No & Draft & Draft \\
\hline Indonesia & Yes & Yes & Yes & Yes \\
\hline Lao PDR & Yes & Yes & Draft & Yes \\
\hline Malaysia & Yes & Yes & Yes & Yes \\
\hline Myanmar & Yes & No & Yes & Yes \\
\hline Philippines & Yes & Yes & Yes & Yes \\
\hline Singapore & Yes & Yes & Yes & Yes \\
\hline Thailand & Yes & Yes & Yes & Yes \\
\hline Vietnam & Yes & Yes & Yes & Yes \\
\hline
\end{tabular}

Source: UNCTAD (n.d.).

\section{Data protection and privacy}

The use of data is central to the digital economy. Accordingly, a robust legal and regulatory regime that addresses issues of data ownership, protects personal data and builds trust, while allowing the legitimate use of data, is a critical requirement. The extent to which countries in the region have legal and regulatory frameworks on the ownership, governance and privacy of data varies. Malaysia, Singapore and the Philippines adopted comprehensive data protection laws earlier last decade. Thailand's personal data protection law was to come into force in May 2020. In Indonesia, sectoral regulations applicable to electronic service providers are already in place and a draft law on data protection is pending presidential approval. Vietnam has a variety of specific regulations in place but no crosscutting data protection law. Cambodia, Brunei, Lao PDR and Myanmar lack publicly announced plans to introduce comprehensive data protection frameworks. 
The ease of transmitting data across borders is central to the growth of cross-border business models. At the transactional level, data underpin the flow of goods and services within countries around the region and between Southeast Asia and its major trading partners. Effective use of data is also a necessary condition for the adoption of cloud technologies that can reduce upfront capital costs and boost productivity (Meltzer and Lovelock 2018). Cross-border data flows generate more economic value than traditional flows of traded goods, according to some estimates. These flows accounted for US\$2.8 trillion of global GDP in 2014 and have the potential to reach US\$11 trillion by 2025 (Manyika and Chui 2015). ${ }^{8}$ Indeed, the ability to move data rapidly and globally is the new growth engine for many businesses.

The region has seen a push by some governments to restrict cross-border data flows, especially of sensitive personal data. The regulatory regimes in Indonesia and Vietnam include data localisation requirements under which businesses are obliged to ensure that various forms of data are processed and stored on servers/facilities physically located within national borders or that at least a copy of the data are available locally and accessible for law enforcement purposes ('data mirroring'). The arguments for such regulations include enhancing national security, protecting personal privacy, aiding law enforcement and preventing foreign surveillance, in addition to appeals to the principle of sovereignty. But governments have also imposed restrictions to support domestic technology sectors or to promote the construction of in-country data centres and the creation of highly skilled technical jobs (FTI Consulting 2017). Such restrictions have economic and trade costs and, according to the European Centre for International Political Economy, may reduce GDP by 0.5 per cent in Indonesia, 0.4 per cent in South Korea and 1.7 per cent in Vietnam (Bauer et al. 2014).

Blanket data localisation restrictions can have widespread impacts beyond the digital economy because of the increasingly central importance of data to economic activity - for example, the use of data to monitor the efficiency of production processes or the performance of engineering parts to identify needs for maintenance or replacement. Moreover, many services critical for increasing productivity (including for SMEs)—for example, research and development services provided from a subsidiary

8 There is no consensus on estimates of the value and impact of data flows and gathering such data is highly challenging. 
to a domestic manufacturing firm, design services for an engineering company or marketing for an agricultural producer-are accessed through cross-border data transfers.

Data localisation regulations should be designed to reduce risk-whether to privacy, from cyberattack or from delays due to law enforcement-to an acceptable level relative to the economic and social benefits, including innovation, expected from the use of the data. ${ }^{9}$ In most cases, legitimate regulatory goals can be achieved at lower costs to growth and trade than those involved in blanket requirements on data localisation. For example, in most countries, only certain types of data are required to be held on local servers (for example, data of national security importance), rather than mandating a blanket requirement. Such approaches should avoid excessive regulatory complexity - for example, by introducing multiple categories of data that are not clearly defined—or relying on imprecise provisions.

The negative impacts of regulations that impede data flows often go unobserved, as many governments do not have the capacity to adequately measure the contributions of data to the digital economy. Governments could improve their measurement of the effects of cross-border data flows and thus the impact of data localisation requirements by increasing the sample sizes used when measuring trade in services and collecting data more often and at a more granular level. They could also collect more detailed and specific data on cross-border data flows and develop better measures to capture how the digital economy contributes to GDP, job growth and productivity. ASEAN could support measurement and data collection by developing a standard nomenclature for terms, standard metrics and indicators related to the digital economy.

A key challenge is finding ways for data to flow freely between countries in the region with different regulatory approaches to privacy. There are ongoing efforts to facilitate data flows through self-regulatory instruments-notably, through the Asia-Pacific Economic Cooperation (APEC) Cross-Border Privacy Rules (CBPR) system, which enables personal data to flow freely even in the absence of two governments having recognised the other's privacy laws as equivalent. Instead, APEC relies on businesses to ensure that data sent to third parties, either domestically or abroad, continue to be protected consistent with APEC privacy principles.

9 This principle has been adopted by the OECD (OECD Secretariat 2015: Principle 5). 
The APEC CBPR regime also requires accountability agents accredited by their local government to monitor and hold businesses accountable for privacy breaches. ${ }^{10}$ To date, in Asia, only Japan has effectively joined the scheme, but it will soon be operational in Singapore and South Korea once their governments appoint accountability agents. The Philippines and Vietnam have expressed an interest in joining the scheme.

Another, complementary approach is to work towards the convergence of data privacy laws across countries. Some Southeast Asian jurisdictions have effectively implemented the high-level principles and concepts embedded in various international legal instruments, frameworks or guidelines into their national legal systems, including the OECD Privacy Principles, EU Directive 95/46/EC (now the General Data Protection Regulation, or GDPR), the APEC Privacy Framework and the ASEAN Data Protection Framework. However, divergence has increased as jurisdictions have prescribed more and more detailed requirements to ensure enforcement and compliance (Hogan Lovells 2018: 4). Local or regional actions seeking to promote the convergence of existing data protection laws should be encouraged.

\section{Cybersecurity}

Cybersecurity threats have wideranging implications for commercial activities and personal privacy and have triggered a range of regulatory responses. Cybersecurity is a function of multiple elements-technical, financial, physical and human resources.

Countries in the region have to date underinvested in the 'hard' and 'soft' infrastructure of cybersecurity. In 2017, expenditure on cybersecurity ranged from 0.22 per cent of GDP in Singapore (the third highest globally) to 0.02 per cent in Indonesia. Overall, ASEAN member countries spent about 0.07 per cent of GDP on cybersecurity—below the global spending average of 0.13 per cent (AT Kearney 2018). According to an assessment by AT Kearney, ASEAN member countries need to increase spending on cybersecurity to between 0.35 per cent and 0.61 per cent of collective GDP_or about US\$171 billion—between 2017 and 2025.

10 Trustarc and JIPDEC have been recognised as accountability agents in the United States and Japan, respectively. 
Singapore, Malaysia, Thailand, the Philippines and, more recently, Indonesia have established national cybersecurity strategies and agencies to coordinate cybersecurity agendas, but specific governance mechanisms and policies are still underdeveloped. One major contributing factor is the global and regional shortage of skills in these areas.

To address current and emerging threats, Southeast Asian governments will need to accelerate the development of national cybersecurity strategies with a well-defined vision, scope, objectives and a practical roadmap for implementation. An approach based on the identification, analysis and evaluation of risk will be crucial.

A regional governance framework to address cybersecurity is also yet to be established. The focus to date has been on including cybercrime in existing frameworks, particularly ASEAN mechanisms. ASEAN is working on a more coordinated approach to develop a comprehensive cybersecurity framework that establishes regional cybersecurity standards and encourages intelligence sharing.

\section{Consumer protection}

Complementing e-commerce and e-transaction laws, consumer protection laws and regulations are essential for building an ecosystem of trust and confidence in electronic transactions. Concerns about potentially greater consumer vulnerabilities through the rise of the digital economy have driven a growing focus on consumer protection related to e-commerce and other aspects of the digital economy. For example, online consumer protection has featured in several ASEAN initiatives and is also a theme in Indonesia’s E-Commerce Roadmap (2017).

Consumer concerns about trust and reliability in e-commerce appear to be a barrier to further growth. The overall lack of trust in online transactions is demonstrated by the fact that, despite an increase in the use of some digital payments—-for example, in Thailand and Malaysia—cash on delivery remains the preferred payment mode in emerging Southeast Asian markets, as noted in the section above.

The main effort at the regional level to address these issues is the ASEAN Strategic Action Plan for Consumer Protection 2025, the implementation of which has focused on information-sharing between regulators, although there are also more ambitious goals, such as creating a cross-border redress system and a rapid alert system on product safety. However, ASEAN's 
initiatives can only advance as far and as quickly as the members themselves can enforce laws and regulations that protect transactions both online and offline, and not all countries have consumer protection laws in place.

\section{Digital entrepreneurship}

Many governments in Southeast Asia are considering options to improve the 'digital entrepreneurship ecosystem' through strengthening the wider business environment and facilitating access to staff with skills appropriate for the digital economy. In addition, governments are increasingly interested in issues specific to digital startups, including access to finance for entrepreneurs, awareness-raising of the potential of the digital economy or targeted financial or other support to help firms grow.

Support to strengthen the foundations of the digital economy, along with the wider business environment, must be balanced with providing targeted support for digital startups. For example, a recent World Bank report on Malaysia's digital economy (Record et al. 2018) recommends the government shift its role from providing a wide range of support programs for entrepreneurship to addressing structural reforms, especially to supply-side factors like access to skills and finance, while avoiding crowding out private investment, channelling government funds into ineffective programs or putting burdensome regulations in place.

\section{Digital government ${ }^{11}$ and digital identification}

The provision of online services to citizens and businesses, typically via a digital government 'platform' or portal (such as www.gov.sg in Singapore or www.malaysia.gov.my in Malaysia), can boost the growth of the digital economy. Developing online business registration platforms and shifting from paper-based to online systems for government approval of crossborder trade shipments can encourage firms to adopt digital technologies. The provision of digital services can help raise digital awareness and literacy. And the digitisation of government payments can increase financial inclusion. For example, 14 per cent of bank account holders in Thailand opened their account to enable receipt of a government transfer. There is considerable potential for increasing financial inclusion through

11 There are numerous definitions of this concept. The term 'e-government' is used to refer to the use of information and communication technologies, specifically the internet, to deliver services to individuals and businesses. The term 'digital government' is used more holistically to refer to 'the use of digital technologies, as an integrated part of governments' modernisation strategies, to create public value' (OECD 2014). 
digitising government payments. For example, in the Philippines, six million unbanked people receive government payments in cash, even though 58 per cent of them own a mobile phone (Demirguc-Kunt et al. 2018). The adoption of government-issued digital IDs can boost financial inclusion by helping to meet 'know your customer' and other regulatory requirements.

Digital ID systems are widely recognised as key enablers for the development of digital government, e-commerce and the digital economy (World Bank 2016b: 194-97). Digital ID systems facilitate reliable authentication of a person's identity on demand and bind users of online transactions with their 'real world' or legal identities. E-commerce and the IoT have also created a need for verifiable digital identities for legal entities and devices. Interoperability of digital IDs across borders can accelerate economic integration and create opportunities for new markets.

\section{Digital identity is a foundational platform with potential for impact across a wide range of sectors}

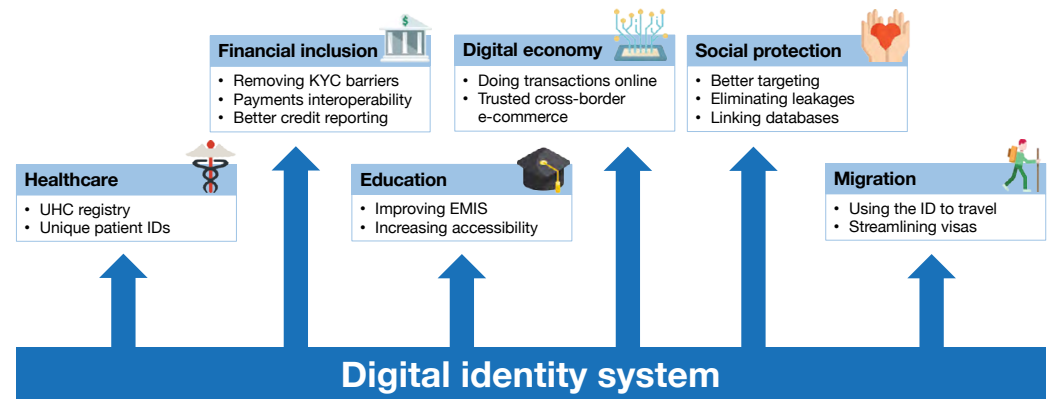

Figure 4.8 Digital IDs in the digital economy ecosystem

$\mathrm{KYC}=$ know your customer

EMIS = educational management information system

$\mathrm{UHC}=$ universal health coverage

Source: Prepared by the Identification for Development (ID4D) team at the World Bank presentation in 2019.

Digital ID is also associated with advancing a range of other development outcomes, including comprehensive social safety nets, streamlined public administration, financial inclusion and the empowerment of women. Five ASEAN member states-Brunei, Indonesia, Malaysia, Singapore and Thailand-have fully digitised their foundational ID system and have established an associated public key infrastructure. The foundational 
ID is widely used in public and private-sector face-to-face transactions, including ubiquitous use of the unique identification number. All these systems, except for Singapore's, use smartcards with data such as private keys and biometrics stored on the chip. Cambodia, Lao PDR and Vietnam are currently piloting digitised foundational ID systems. Myanmar has listed the development of a digital ID system as one of 12 priorities in its national economic policy. ${ }^{12}$

\section{Towards a regional digital economy?}

Almost all governments in Southeast Asia have developed national strategies or high-level plans, endorsed at the head of government or a similar level, for growing the digital economy, but implementation remains a challenge. A robust assessment of where the market is adjusting well to digital transformation would help determine where government intervention would be most useful and where it is not required. Such a targeted approach to intervention would be less challenging to implement and would help establish a logical sequence for the implementation of various initiatives. Furthermore, more effective consultation and feedback mechanisms are required for policymakers to gain the perspectives of private-sector firms at every stage of national digital economy strategiesfrom conception to implementation and monitoring. Government strategies on the digital economy will need to include implementation plans with concrete targets, timelines and institutional coordination to ensure delivery and accountability.

Given a range of potentially important cross-country dimensions of the digital economy, regional cooperation-for example, through ASEANcould be leveraged to strengthen the enabling environment for the growth of the digital economy in individual Southeast Asian countries as well as to facilitate deeper integration between national economies. Digital platforms-for example, for e-commerce, transport and financial services-are increasingly transnational. Greater regional cooperation

12 'Foundational ID system' is an ID system used for general purposes (for example, national IDs and birth certificates) as the root of someone's identity. By comparison, a functional ID system is intended for a specific purpose- for example, a passport is for travel, a driver's licence is for permission to drive. Public key infrastructure is widely known in digital ID and ICT circles. Essentially, it is a technology for authenticating people or things by using cryptography to match a private key (a digital certificate held by a user) and a public key (held by an authority). A unique ID number (for example, a national ID number) is one type of credential issued by a foundational ID system. Other examples include a card or a username (World Bank 2021a). 
could help address many of the issues identified in this chapter, including data privacy (to improve the coherence of legal frameworks), cybersecurity (to prevent and respond to threats) and consumer protection (to improve cross-border appeal and redress mechanisms), among others. Identifying concrete measures that can be taken in these areas is an important area for future analysis and policy cooperation in Southeast Asia.

ASEAN could encourage its members to develop the necessary infrastructure for information and communication technology (ICT) development, reduce barriers to participation in digital markets and harmonise regulations. Supporting development of the digital economy will also strengthen ASEAN's overall objective of promoting regional economic integration. ASEAN has adopted initiatives to support the growth of the digital economy, including the first and second ASEAN ICT masterplans (AIM2015 and AIM2020) and the Master Plan on ASEAN Connectivity 2025, while high-level ASEAN agreements-notably, the 2015 and 2025 economic blueprints - demonstrate a broadening of the vision for the digital economy in the region.

However, there is scope to go further in cooperation on the digital economy at the ASEAN level, especially in terms of detailed actions, timelines and targets. There are no monitoring or ranking mechanisms to evaluate progress at the national or regional level in developing critical enablers, such as the impact of privacy laws, data protection or incentives to support universal broadband access, mobile financial services, e-commerce and other key areas of the digital economy. Though the current approach recognises the importance of regulatory harmonisation, it offers no concrete principles for how regulations need to be extended and harmonised to create a single digital market, including by taking interim steps such as developing a common standard that applies to digital services, like the European Union's privacy directive or the streamlined sales tax system in the United States for interstate e-commerce transactions. Clearer links could be drawn between digital economy efforts and longstanding ASEAN priorities in areas such as trade facilitation. The ASEAN E-commerce Consultative Committee offers a forum to pursue this. ASEAN is currently developing a digital data governance framework for consideration by member states.

APEC has made more rapid progress than ASEAN in developing specific, in-depth guidelines, principles and capacity-building programs to facilitate the adoption of digital economy principles_-namely, in key areas such 
as data privacy, cybersecurity, electronic trade, digital infrastructure and micro, small and medium-sized enterprise development. ASEAN could learn from this experience in developing a common, unified approach to issues like data privacy.

\section{Conclusion}

The digital economy is widely seen as presenting significant opportunities to propel future growth in Southeast Asia. The region already has rapidly rising internet usage, although business, and indeed government, use of digital technology remains below its potential.

A concerted effort by the region's governments, both individually and collectively, to strengthen the foundations of the digital economy could address five key areas: connectivity, digital payments, digital skills, logistics, and crosscutting digital policies and regulations. Some regulatory gaps need to be filled (such as on consumer protection and data privacy) and some regulations could be adjusted to more effectively achieve policy goals (such as on cross-border data localisation). In some areas, governments should step back and allow the private sector to innovate and invest in digitisation. The development and implementation of national and regional digital economy plans could be improved by shifting from high-level planning to strengthened implementation and coordination across governments, by fostering greater private-sector participation in planning, implementation and monitoring of plans, and pursuing concrete initiatives to address policy and regulatory blockages. Beyond setting the overall policy and regulatory framework for the digital economy, governments have a direct role to play, including through supporting digital entrepreneurship and other digital initiatives.

Governments, businesses and citizens alike are increasingly concerned about various risks associated with digitisation, some of which-like inadequate protection of personal data and cybersecurity threats-are directly linked to the technologies associated with the digital economy. Others relate to the new types of business models developing in the digital economy-for example, the challenges to the protection of consumer rights when buyers and sellers are physically separated and, increasingly, in different countries. Similarly, the slow pace of consumer adoption of digital payments is in part due to perceived risks and lack of trust in 
new payment systems. While thinking about potential responses to these challenges has begun, further analysis at the country level is required on these risks and the appropriate responses.

Other risks are longer term, with the nature of the risk and the appropriate responses less well defined. For example, automation is widely perceived as presenting risks to workers, although concrete evidence of this in Southeast Asia is limited. Further analysis is required to understand how skills demands and jobs change as the digital economy grows and what the implications are for national education systems, training and skills upgrading initiatives and national social protection schemes. ${ }^{13}$ Growing concerns about the risks presented by using the internet to spread misinformation could lead to responses that restrict the medium's potential as a means of open exchange of ideas and information. The discussion on data flows and cybersecurity highlighted that heavy restrictions on the use of the internet - for example, through data localisation requirements-are not necessary to protect citizens' interests and would impair the growth of the digital economy.

Finally, digitisation offers various ways to boost inclusiveness. The rapidly decreasing cost of broadband (especially mobile broadband) is helping more people access information and connect to economic opportunities. For example, e-commerce platforms are bringing new entrepreneurs into international trade. At the same time, there are still significant disparities in the cost and quality of internet access - most visible between central and more remote regions of large, geographically dispersed countries like Indonesia, but also between urban and rural areas of countries like Thailand, Vietnam and Malaysia. Similarly, the wide discrepancies in quality and affordability of internet access between countries also needs to be addressed to boost the inclusiveness of the digital economy in the region. While the digital economy can help create new opportunities to overcome barriers in the offline economy, those who lack adequate connectivity or the skills to participate risk being left behind.

13 Another area for future analysis is the issue of digital economy taxation. Governments in Southeast Asia are becoming concerned that e-commerce could be eroding the tax base and creating disadvantages for locally based firms. As policy responses in the region are evolving, this chapter does not address this topic in detail. 
Table 4.5 Policy priorities summary for developing Southeast Asian countries

\begin{tabular}{|c|c|c|c|}
\hline & $\begin{array}{l}\text { Cambodia, Lao PDR, } \\
\text { Myanmar }\end{array}$ & $\begin{array}{l}\text { Indonesia, Malaysia, } \\
\text { Thailand, Vietnam, } \\
\text { Philippines }\end{array}$ & $\begin{array}{l}\text { Regional } \\
\text { cooperation }\end{array}$ \\
\hline \multirow[t]{3}{*}{ Connectivity } & $\begin{array}{l}\text { Address barriers } \\
\text { and strengthen } \\
\text { enabling conditions } \\
\text { for accelerated } \\
\text { private investment in } \\
\text { broadband }\end{array}$ & $\begin{array}{l}\text { Allow greater } \\
\text { competition along the } \\
\text { broadband value chain }\end{array}$ & $\begin{array}{l}\text { Cross-border } \\
\text { connectivity } \\
\text { including } \\
\text { regulatory } \\
\text { harmonisation }\end{array}$ \\
\hline & & $\begin{array}{l}\text { Management of } \\
\text { radio spectrum } \\
\text { (frequencies for mobile } \\
\text { communications) } \\
\end{array}$ & \\
\hline & & $\begin{array}{l}\text { Passive infrastructure } \\
\text { sharing and rights-of- } \\
\text { way }\end{array}$ & \\
\hline Payments & $\begin{array}{l}\text { Facilitate innovation in } \\
\text { digital payments }\end{array}$ & $\begin{array}{l}\text { Promote use (for } \\
\text { example, payments for } \\
\text { government services) } \\
\text { and address regulatory } \\
\text { gaps }\end{array}$ & $\begin{array}{l}\text { Promote } \\
\text { interoperability }\end{array}$ \\
\hline \multirow[t]{2}{*}{ Skills } & $\begin{array}{l}\text { Continue upgrading } \\
\text { basic education, } \\
\text { including a focus on } \\
\text { building digital skills at } \\
\text { the primary school level }\end{array}$ & $\begin{array}{l}\text { Integrate digital skills } \\
\text { development across } \\
\text { the curriculum including } \\
\text { technical as well as } \\
\text { 'soft' skills. Implement } \\
\text { approaches for lifelong } \\
\text { learning through the } \\
\text { education system }\end{array}$ & $\begin{array}{l}\text { Enable greater } \\
\text { regional mobility } \\
\text { of skilled workers, } \\
\text { including through } \\
\text { mutual recognition } \\
\text { of qualifications }\end{array}$ \\
\hline & $\begin{array}{l}\text { Targeted digital skills } \\
\text { training, especially for } \\
\text { small and medium-sized } \\
\text { enterprises }\end{array}$ & $\begin{array}{l}\text { Deepen industry- } \\
\text { business collaboration } \\
\text { to identify future skills } \\
\text { needs and meet short- } \\
\text { term gaps }\end{array}$ & \\
\hline \multirow[t]{2}{*}{ Logistics } & $\begin{array}{l}\text { Issue clear regulations } \\
\text { for small-parcel trade }\end{array}$ & $\begin{array}{l}\text { Risk-based approach to } \\
\text { facilitating small-parcel } \\
\text { trade }\end{array}$ & $\begin{array}{l}\text { Harmonised } \\
\text { regional de } \\
\text { minimis thresholds } \\
\text { and simplified } \\
\text { procedures }\end{array}$ \\
\hline & $\begin{array}{l}\text { Address regulatory } \\
\text { barriers to entry in } \\
\text { logistics }\end{array}$ & $\begin{array}{l}\text { Enable innovation } \\
\text { in digitised logistics } \\
\text { services }\end{array}$ & \\
\hline
\end{tabular}




\begin{tabular}{|c|c|c|c|}
\hline & $\begin{array}{l}\text { Cambodia, Lao PDR, } \\
\text { Myanmar }\end{array}$ & $\begin{array}{l}\text { Indonesia, Malaysia, } \\
\text { Thailand, Vietnam, } \\
\text { Philippines }\end{array}$ & $\begin{array}{l}\text { Regional } \\
\text { cooperation }\end{array}$ \\
\hline \multirow[t]{2}{*}{ Data policies } & $\begin{array}{l}\text { Ensure legal regime } \\
\text { exists for data privacy } \\
\text { and protection }\end{array}$ & $\begin{array}{l}\text { Build regulatory } \\
\text { capacity and raise } \\
\text { consumer and business } \\
\text { awareness }\end{array}$ & $\begin{array}{l}\text { Pathway to } \\
\text { regulatory } \\
\text { coherence }\end{array}$ \\
\hline & $\begin{array}{l}\text { Caution on introducing } \\
\text { data localisation }\end{array}$ & $\begin{array}{l}\text { Roll back blanket data } \\
\text { localisation policies } \\
\text { and introduce data } \\
\text { classification-based } \\
\text { approaches }\end{array}$ & $\begin{array}{l}\text { Open regional } \\
\text { regime on data }\end{array}$ \\
\hline Cybersecurity & $\begin{array}{l}\text { Ensure laws cover } \\
\text { cybercrime and build } \\
\text { enforcement capacity }\end{array}$ & $\begin{array}{l}\text { Boost public and } \\
\text { private spending on } \\
\text { cybersecurity and } \\
\text { address skills gaps }\end{array}$ & $\begin{array}{l}\text { Regional } \\
\text { regulatory and } \\
\text { enforcement } \\
\text { collaboration, } \\
\text { including } \\
\text { overarching } \\
\text { governance } \\
\text { framework }\end{array}$ \\
\hline $\begin{array}{l}\text { Consumer } \\
\text { protection }\end{array}$ & $\begin{array}{l}\text { Establish legal regime } \\
\text { for consumer protection }\end{array}$ & $\begin{array}{l}\text { Strengthen regulatory } \\
\text { capacity for consumer } \\
\text { protection, awareness } \\
\text { and outreach }\end{array}$ & $\begin{array}{l}\text { Regional } \\
\text { complaint and } \\
\text { enforcement } \\
\text { mechanisms }\end{array}$ \\
\hline $\begin{array}{l}\text { Supporting } \\
\text { digital } \\
\text { entrepreneurs }\end{array}$ & $\begin{array}{l}\text { Provide targeted } \\
\text { support for skills } \\
\text { upgrading and } \\
\text { technology adoption } \\
\text { as overall digital } \\
\text { foundations are } \\
\text { strengthened }\end{array}$ & $\begin{array}{l}\text { Ensure coordination of } \\
\text { SME support programs } \\
\text { while still focusing on } \\
\text { structural reforms }\end{array}$ & $\begin{array}{l}\text { Support } \\
\text { internationalisation } \\
\text { of SMEs } \\
\text { through regional } \\
\text { integration }\end{array}$ \\
\hline Digital ID & $\begin{array}{l}\text { Consolidate } \\
\text { implementation of digital } \\
\text { IDs }\end{array}$ & $\begin{array}{l}\text { Digital ID as a basis for } \\
\text { transactions }\end{array}$ & $\begin{array}{l}\text { Regional } \\
\text { compatibility of } \\
\text { digital IDs }\end{array}$ \\
\hline $\begin{array}{l}\text { Plans and } \\
\text { strategies }\end{array}$ & $\begin{array}{l}\text { Develop actionable } \\
\text { digital economy } \\
\text { strategies with } \\
\text { the participation } \\
\text { of government } \\
\text { and private-sector } \\
\text { stakeholders }\end{array}$ & $\begin{array}{l}\text { Identify concrete } \\
\text { actions and institutional } \\
\text { responsibilities to } \\
\text { implement and monitor } \\
\text { digital economy } \\
\text { strategies or master } \\
\text { plans }\end{array}$ & $\begin{array}{l}\text { Regional vision for } \\
\text { open, integrated } \\
\text { digital economy }\end{array}$ \\
\hline
\end{tabular}




\section{References}

Ahsan, A., Mattoo, A., Gootiiz, B., Saez, J.S., Molineuvo, M. and Walkenhorst, P. 2015. ASEAN services integration report: A joint report by the ASEAN Secretariat and the World Bank. Working Paper No. 100637. Washington, DC: World Bank Group. Available from: documents.worldbank.org/curated/ en/759841468178459585/ASEAN-services-integration-report-a-joint-reportby-the-ASEAN-Secretariat-and-the-World-Bank.

Akamai. 2017. Akamai's [State of the Internet]: Q1 2017 report. Vol. 10, no. 1. Cambridge, MA: Akamai.

AT Kearney. 2018. Cybersecurity in ASEAN: An urgent call to action. Singapore: Kearney Southeast Asia. Available from: www.kearney.com/web/southeastasia/article?/a/cybersecurity-in-asean-an-urgent-call-to-action.

Bauer, M., Hosuk, L.-M., van der Marel, E. and Verschelde, B. 2014. The costs of data localisation: Friendly fire on economic recovery. ECIPE Occasional Paper No. 3/2014. Brussels: European Centre for International Political Economy. Available from: ecipe.org/wp-content/uploads/2014/12/OCC32014_1.pdf.

Beschorner, N., Bartley Johns, M., Guermazi, B., Treadwell, J.L., Prakosa, P.W.B., Abdul Karim, N.A.B., Van Tuijll, D.A., Bennis, L., Nicoli, M., Van Rees, J. and Girot, C.A.H.M. 2019. The digital economy in Southeast Asia: Strengthening the foundations for future growth (English). Working Paper No. 137143. Washington, DC: World Bank Group. Available from: documents. worldbank.org/curated/en/328941558708267736.

Demirguc-Kunt, A., Klapper, L., Singer, D., Ansar, S. and Hess, J.R. 2018. The Global Findex Database 2017: Measuring financial inclusion and the fintech revolution (English). Washington, DC: World Bank Group. Available from: documents.worldbank.org/curated/en/332881525873182837/The-GlobalFindex-Database-2017-Measuring-Financial-Inclusion-and-the-FintechRevolution.

FTI Consulting. 2017. Localization to Fragment Data Flows in Asia. Washington, DC: FTI Consulting. Accessed from: www.fticonsulting-asia.com/ $/$ media/ Files/apac-files/insights/articles/localization-to-fragment-data-flows-asia.pdf [page discontinued].

Fujita, A. 2017. 'YouTube bets its future on Asia.' CNBC, 26 April. Available from: www.cnbc.com/2017/04/26/youtube-bets-its-future-on-asia.html. 
Girot, C. (ed.). 2018. Regulation of Cross-Border Transfers of Personal Data in Asia. Singapore: Asian Business Law Institute. Available from: abli.asia/ PUBLICATIONS/Regulation_of_Cross-border_Transfers_of_Personal_Data _in_Asia.

Google, Temasek and Bain \& Company. 2019. e-Conomy SEA 2019. Available from: www.blog.google/documents/47/SEA_Internet_Economy_Report_2019.pdf.

GSM Association (GSMA). 2019. State of the Industry Report on Mobile Money 2018. London: GSMA. Available from: www.gsma.com/mobilefordevelopment/ wp-content/uploads/2019/02/2018-State-of-the-Industry-Report-on-MobileMoney.pdf.

Hogan Lovells. 2018. Asia Pacific Data Protection and Cyber Security Guide 2018: Shifting landscapes across the Asia-Pacific region. London: Hogan Lovells.

International Telecommunication Union (ITU). 2016. Measuring the Information Society Report 2016. Geneva: ITU. Available from: www.itu.int/en/ITU-D/ Statistics/Pages/publications/mis2016.aspx.

International Telecommunication Union (ITU). 2017. Measuring the Information Society Report 2017. Volume 1. Geneva: ITU. Available from: www.itu.int/en/ ITU-D/Statistics/Pages/publications/mis2017.aspx.

International Telecommunications Union (ITU). 2018. Measuring the Information Society Report 2018. Volume 1. Geneva: ITU. Available from: www.itu.int/en/ ITU-D/Statistics/Pages/publications/misr2018.aspx.

Kemp, S. 2017. Digital in Southeast Asia in 2017. Special Report. New York: We Are Social Inc. Available from: wearesocial.com/special-reports/digitalsoutheast-asia-2017.

Manyika, J. and Chui, M. 2015. 'By 2025, Internet of things applications could have US\$1 1 trillion impact.' Fortune, 23 July. Available from: www.mckinsey. $\mathrm{com} / \mathrm{mgi} /$ overview/in-the-news/by-2025-internet-of-things-applicationscould-have-11-trillion-impact.

Manyika, J., Lund, S., Bughin, J., Woetzel, J., Stamenov, K. and Dhingra, D. 2016. Digital globalization: The new era of global flows. Report, 24 February. New York: McKinsey Global Institute. Available from: www.mckinsey.com/ business-functions/digital-mckinsey/our-insights/digital-globalization-thenew-era-of-global-flows. 
Meltzer, J.P. and Lovelock, P. 2018. Regulating for a digital economy: Understanding the importance of cross-border data flows in Asia. Global Economy and Development Working Paper 113. Washington, DC: Brookings Institution. Available from: www.brookings.edu/wp-content/uploads/2018/03/digitaleconomy_meltzer_lovelock_web.pdf.

Organisation for Economic Co-operation and Development (OECD). 2014. Recommendation of the Council on Digital Government Strategies. Paris: OECD Publishing. Available from: www.oecd.org/gov/digital-government/ Recommendation-digital-government-strategies.pdf.

Organisation for Economic Co-operation and Development (OECD). 2016. New skills for the digital economy: Measuring the demand and supply of ICT skills at work. Digital Economy Papers No. 258. Paris: OECD Publishing. doi.org/10.1787/5jlwnkm2fc9x-en.

Organisation for Economic Co-operation and Development (OECD). 2017. OECD Southeast Asia Regional Forum: Opportunities and policy challenges of digitalisation in Southeast Asia, 24 August 2017, Anantara Siam Bangkok Hotel, Bangkok, Thailand. Background Note. Paris: OECD. Available from: www.oecd.org/southeast-asia/events/regional-forum/Forum_Note_Digital_ Transformation_STI.pdf.

Organisation for Economic Co-operation and Development (OECD) Secretariat. 2015. New skills for the digital economy: Measuring the demand for ICT skills at work. Paper, 8 July. Paris: Directorate for Science, Technology and Innovation Committee on Digital Economy Policy, OECD. Available from: one.oecd. org/document/DSTI/ICCP/IIS(2015)4/en/pdf.

Prologis. 2016. Global E-Commerce Impact on Logistics Real Estate. September. San Francisco: Prologis. Available from: www.prologis.com/about/logisticsindustry-research/global-e-commerce-impact-logistics-real-estate.

Record, R.J.L., Larson, B.R., Teh Sharifuddin, S.B. and Chong, Y.K. 2018. Malaysia's digital economy: A new driver of development (English). Working Paper No. 129777. Washington, DC: World Bank Group. Available from: documents.worldbank.org/curated/en/435571536244480293/MalaysiasDigital-Economy-A-New-Driver-of-Development.

Schwab, K. (ed.). 2016. The Global Competitiveness Report 2015-2016: Insight report. Geneva: World Economic Forum. Available from: www3.weforum. org/docs/gcr/2015-2016/Global_Competitiveness_Report_2015-2016.pdf.

TeleGeography. 2021. Website. Carlsbad, CA: PriMetrica, Inc. Available from: www2.telegeography.com. 
United Nations Commission on International Trade Law (UNCITRAL). 1999. Model Law on Electronic Commerce, with Guide to Enactment, 1996: With additional articles as adopted in 1998. New York: United Nations.

United Nations Conference on Trade and Development (UNCTAD). n.d. 'Summary of adoption of e-commerce legislation worldwide.' UNCTAD Global Cyberlaw Tracker. Geneva: UNCTAD. Available from: unctad.org/en/Pages/ DTL/STI_and_ICTs/ICT4D-Legislation/eCom-Global-Legislation.aspx.

United Nations Educational, Scientific and Cultural Organization (UNESCO). 2018. A global framework of reference on digital literacy skills for Indicator 4.4.2. Information Paper No. 51, June. Montreal: UNESCO Institute for Statistics. Available from: uis.unesco.org/sites/default/files/documents/ip51-globalframework-reference-digital-literacy-skills-2018-en.pdf.

United Overseas Bank (UOB). 2017. State of fintech in ASEAN. FinTech White Paper R2a. Singapore: UOB. Available from: www.uobgroup.com/ techecosystem/pdf/UOB-State-of-FinTech-in-ASEAN.pdf.

Universal Postal Union (UPU). 2017. Integrated Index for Postal Development (2IPD): 2016 results. Bern: UPU. Available from: www.upu.int/en/Publications/2IPD/ Integrated-Index-for-Postal-Development-(2IPD)---2016-results.

We Are Social and Hootsuite. 2019. Digital 2019. Global Digital Report. New York: We Are Social Inc. Available from: wearesocial.com/global-digital-report-2019.

World Bank. 2016a. Digital Adoption Index. Washington, DC: World Bank Group. Available from: wbgfiles.worldbank.org/documents/dec/digitaladoption-index.html.

World Bank. 2016b. World Development Report 2016: Digitaldividends. Washington, DC: World Bank Group. Available from: documents.worldbank.org/curated/ en/896971468194972881/pdf/102725-PUB-Replacement-PUBLIC.pdf.

World Bank. 2018a. The Global Findex Database 2017. Washington, DC: World Bank Group. Available from: globalfindex.worldbank.org.

World Bank. 2018b. Logistics Performance Index (LPI) 2018. Washington, DC: World Bank Group. Available from: lpi.worldbank.org/international/global.

World Bank. 2019. World Bank East Asia and Pacific Economic Update, October 2019: Weathering growing risks (English). Washington, DC: World Bank Group. Available from: documents.worldbank.org/curated/en/598201570731087175/ World-Bank-East-Asia-and-Pacific-Economic-Update-October-2019Weathering-Growing-Risks. 
NEW DIMENSIONS OF CONNECTIVITY IN THE ASIA-PACIFIC

World Bank. 2021a. Identification for Development (ID4D). Washington, DC: World Bank Group. Available from: id4d.worldbank.org/.

World Bank. 2021b. World Development Indicators. DataBank. Washington, DC: World Bank Group. Available from: databank.worldbank.org/source/worlddevelopment-indicators.

World Economic Forum (WEF). 2017. The Global Competitiveness Report 2016-17. Geneva: WEF. 
This text is taken from New Dimensions of Connectivity in the Asia-Pacific, edited by Christopher Findlay and Somkiat Tangkitvanich, published 2021 by ANU Press, The Australian National University, Canberra, Australia.

doi.org/10.22459/NDCAP.2021.04 